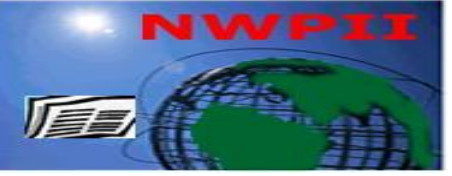

American Journal of Biomedical Sciences

ISSN: 1937-9080

nwpii.com/ajbms

\title{
Iron, Oxidative Stress, and Cell Signaling in the Pathogeneses of Coal Workers' Pneumoconiosis, Silicosis, and Asbestosis
}

\author{
Xi Huang* \\ Departments of Environmental Medicine and Medicine, New York University School of Medicine, 550 First Avenue, \\ HJD Room 1600, New York, NY 10016, USA \\ * Corresponding author \\ Departments of Environmental Medicine and Medicine \\ NYU School of Medicine \\ 550 First Avenue \\ HJD Room 1600 \\ New York, NY 10016, USA \\ Fax: 212-598-7604 \\ Email: Xi.Huang@nyumc.org
}

Received: 6 January 2011; | Revised: 1 February 2011; | Accepted: 27 February 2011

\begin{abstract}
Coal workers' pneumoconiosis (CWP), silicosis, and asbestosis were the most common occupational diseases in the $20^{\text {th }}$ Century. The passage of the Mine Health and Safety Act in 1968 resulted in reduction of occupational exposures to coal, silica, and asbestos fibers and, thus, decreased incidence of the diseases. However, the most recent data showed that, from the beginning of the $21^{\text {st }}$ Century, a significant increase in the occurrence and severity of CWP took place in the U.S. This occurrence necessitates a comprehensive review of this issue. Among many factors, cumulative dust exposure (CDE), a product of dust concentration and working tenure, is the most important cause of the disease. The molecular mechanisms mostly center on iron-mediated oxidative stress and cell signaling, leading to inflammation, possibly epithelial mesenchymal transition (EMT) to fibroblasts, and ultimately fibrotic changes. In order to combat the recent increase in CWP, reducing coal dust levels and decreasing the toxicity of the coal at the work setting are the first practical measures to take. Exposure biomarkers, which are based on iron, and early disease biomarkers in inflammation and EMT can be developed for early detection before the conventional chest $x$-ray diagnosis is possible. In summary, through dust reduction, delay of mining highly toxic coal, and identification of susceptible workers, CWP is preventable.
\end{abstract}

Keywords: coal, iron, oxidative stress, cell signaling, pneumoconiosis.

\footnotetext{
Abbreviations: AMs: alveolar macrophages; BAL: broncho-alveolar lavage; CDE: cumulative dust exposure; CWP: coal workers' pneumoconiosis; EMT: epithelial mesenchymal transition; IL: interleukin; OEL: occupational exposure limit; PMF: progressive massive fibrosis; ROS: reactive oxygen species; TNF- $\alpha$ : tumor necrosis factor-alpha.
} 


\section{Introduction}

The World Coal Institute estimates that proven coal reserves at current production levels of approximately 5 billion tons per year will last at least 155 years (http://www.worldcoal.org). Should oil prices remain high, coal and coal products will play an increasingly important role in fulfilling the energy needs of our society and around the world. Today, $51 \%$ of the electricity in the U.S is generated by coal-fired power plants, and the Department of Energy (http://www.fossil.energy.gov) forecasts that coal will account for about $57 \%$ by the year 2030 .

The most notorious health problem associated with coal mining is the black lung or coal workers' pneumoconiosis (CWP), a lung disease contracted from prolonged exposure to coal dusts. CWP, silicosis, and asbestosis are three of the most common occupational diseases of the $20^{\text {th }}$ Century. Research on coal, silica, and asbestos fiber has led to effective control of dust exposure levels and reduced disease rates in the past. However, from the beginning of the $21^{\text {st }}$ Century to the time of the most recent data in 2006, there has been a significant increase in the occurrence and severity of CWP and progressive massive fibrosis (PMF) in U.S. coal miners (1). For example, during this short time period, CWP prevalence is more than doubled among coal miners with greater than 20 years' tenure. The goal of this review was to compare pathogenesis of CWP with those of silicosis and asbestosis. A review on the successful reduction of silicosis and asbestosis may lead to the development of effective preventive measures and ultimately a decline in CWP prevalence.

\section{Definitions of CWP, silicosis, and asbestosis}

CWP, silicosis, and asbestosis are all pneumoconioses, which are caused by overload of coal dust, silica, and asbestos in the lung, respectively. The term "pneumoconiosis" embraces non-neoplastic reactions of the lungs to inhaled mineral and organic dusts, and the resultant alterations in their structure, excluding asthma, bronchitis, and emphysema $(2,3)$. It can be defined as a dust burden disease in the lungs and the tissue's reaction to its presence (4). CWP results from inhalation of coal dust, a complex mixture usually containing small amounts of free crystalline silica, clay, sulfides such as pyrite, carbonate, and carbonaceous materials (3). Coal is a combustible, sedimentary, organic-rich rock, composed mainly of carbon, hydrogen, and oxygen $(5,6)$. Organic material dominates, typically representing $75-90 \%(\mathrm{w} / \mathrm{w})$ of a dry coal. These organic materials occur in different petrographic types, called "macerals", which reflect the nature of the precursor plant material and differ in their color/reflectance, morphology, and chemical and physical properties. The inorganic portion of coal comprises $10-25 \%$ (w/w) and is composed of phyllosilicates (kaolinite, illite, etc.), quartz, carbonates, sulfides, sulfates, and other minerals (6). In general, $\mathrm{Al}$ and $\mathrm{Fe}$ are the main metals existing as aluminosilicates and pyrite in the coals, and $\mathrm{As}, \mathrm{Ni}, \mathrm{Zn}, \mathrm{Cd}, \mathrm{Co}, \mathrm{Cu}$ are trace metals that represent only a very small fraction of the inorganic constituents (7).

Silicosis is a fibrotic disease of the lungs produced by inhalation of dust containing silicon dioxide $\left(\mathrm{SiO}_{2}\right)$, primarily in the free crystalline form, also commonly referred to as quartz or free silica (8). Silica may also exist in a noncrystalline form (amorphous). Crystalline silica is the most toxic form of silica, posing a major health hazard to workers (9). Because of the abundance of silica in the environment and its widespread use in consumer products and industrial manufacturing, exposure occurs in a large variety of industries and occupational settings (8).

Asbestosis is a fibrotic lung disease resulting from the inhalation of asbestos fibers (10). It occurs after long-term, heavy exposure to asbestos. Asbestos is a general term used to describe a class of minerals that occur in deposits throughout the world and is the smallest naturally occurring fiber. Due to its flexibility, durability, and resistance to heat and chemical corrosions, asbestos became widely used in industry. Although its use has been banned in most developed countries, exposure still occurs in occupational settings and also occasionally in domestic settings. 


\section{Results and discussions}

\subsection{Cumulative dust exposure (CDE) and pneumoconiosis development}

A major focus of epidemiological studies in CWP, silicosis, and asbestosis is to offer a quantitative estimate of risk for disease development. The study on South African miners was among the first to question the protectiveness of the occupational exposure limit (OEL) and to indicate that exposure at $0.1 \mathrm{mg} / \mathrm{m}^{3}$ for a $40-$ or $45-y r$ working lifetime might not protect against silicosis (11). Since then, a number of other epidemiological studies reported varying estimates of silicosis risk associated with a lifetime of work at the current occupational standard (8). It has been suggested that the dose-response curve for silicosis is nonlinear, with risk increasing more rapidly at higher exposure levels (11).

As a result of the increasing emphasis on exposure-response characterizations for occupational hazards, a quantitative estimation of exposure was developed in CWP epidemiology $(12,13)$. Cumulative dust exposure (CDE) estimates were calculated for each miner by multiplying the coal dust concentration and the time worked underground. $\mathrm{CDE}$ estimates are commonly expressed as units of gram-years per cubic meter $\left(\mathrm{g}-\mathrm{yr} / \mathrm{m}^{3}\right)$ (14). Application of CDE to exposure-response led to stronger relationships between coal dust exposure and prevalence of CWP than those obtained by using surrogate measures of exposure, such as tenure underground (15-18).

$\mathrm{CDE}$ is the most important risk factor for CWP, silicosis, and asbestosis (Figure 1). The current standard of the OEL for quartz is 0.05 $\mathrm{mg} / \mathrm{m}^{3}$, which may not be sufficient to protect workers' health (19-21). Recently, the OEL for asbestos was lowered from 2 fibers $/ \mathrm{m}^{3}$ to 0.1 fibers $/ \mathrm{m}^{3}$ over an 8 -hr time period. The OEL for coal dust was doubled from $1 \mathrm{mg} / \mathrm{m}^{3}$ to $2 \mathrm{mg} / \mathrm{m}^{3}$ at the beginning of the Century and has recently been proposed to be reduced back to $1 \mathrm{mg} / \mathrm{m}^{3}$. Increased production and longer hours worked (22) as well as small coal mine size with less sophisticated dust protection (23) could result in the recent increase in the prevalence and severity of CWP. Moreover, other factors such as quartz content or levels of bioavailable iron vary from one coalmine region to another (24). Increased exposure to these two potential active components due to deep drilling through siliceous rock may explain why the prevalence of CWP is increased more in Kentucky, Virginia, and West Virginia than in other regions in the U.S. $(24,25)$.

The pathogenesis of CWP appears similar to those of silicosis and asbestosis. Cells are able to repair injuries by themselves, but when injury exceeds repair, a permanent damage could occur (26). When injury exceeds repair, a permanent damage could occur in the cells and eventually extend to the lung tissue and lead to the development of CWP, silicosis, and asbestosis (Figure 1).

\subsection{Iron, oxidative stress, and cell signaling in CWP, silicosis, and asbestosis}

CWP, silicosis, and asbestosis are considered to be human lung pathologies related to oxidative stress. Oxidative stress is a disturbance in the oxidant/antioxidant steady state in favor of oxidants, which leads to cellular damage. The presumed mechanism is through the ability of reactive oxygen species (ROS) to induce biochemical alterations in macromolecules such as DNA, lipids, and proteins (27). Iron is one of the best transition metals capable of producing ROS through Fenton, Haber-Weiss, and autoxidation reactions (28). Figure 2 illustrates that the molecular mechanisms of these pathologies are mostly centered on iron, a common constituent in coal (29), asbestos $(10,30)$, and silica (31). To support this view, asbestos-exposed individuals have altered iron homeostasis in the lungs as manifested by increased levels of bronchoalveolar lavage fluid (BALF) iron, transferrin, transferrin receptor, lactoferrin, and ferritin (32). Moreover, levels of iron bound to low molecular weight ligands, ferritin, and lipid peroxidation were significantly higher in lung epithelial A549 cells treated with various coals than in control cells, with decreasing iron levels in coals from Utah < West Virginia < Pennsylvania, in parallel to the prevalence of CWP in these coal mine regions (33). 

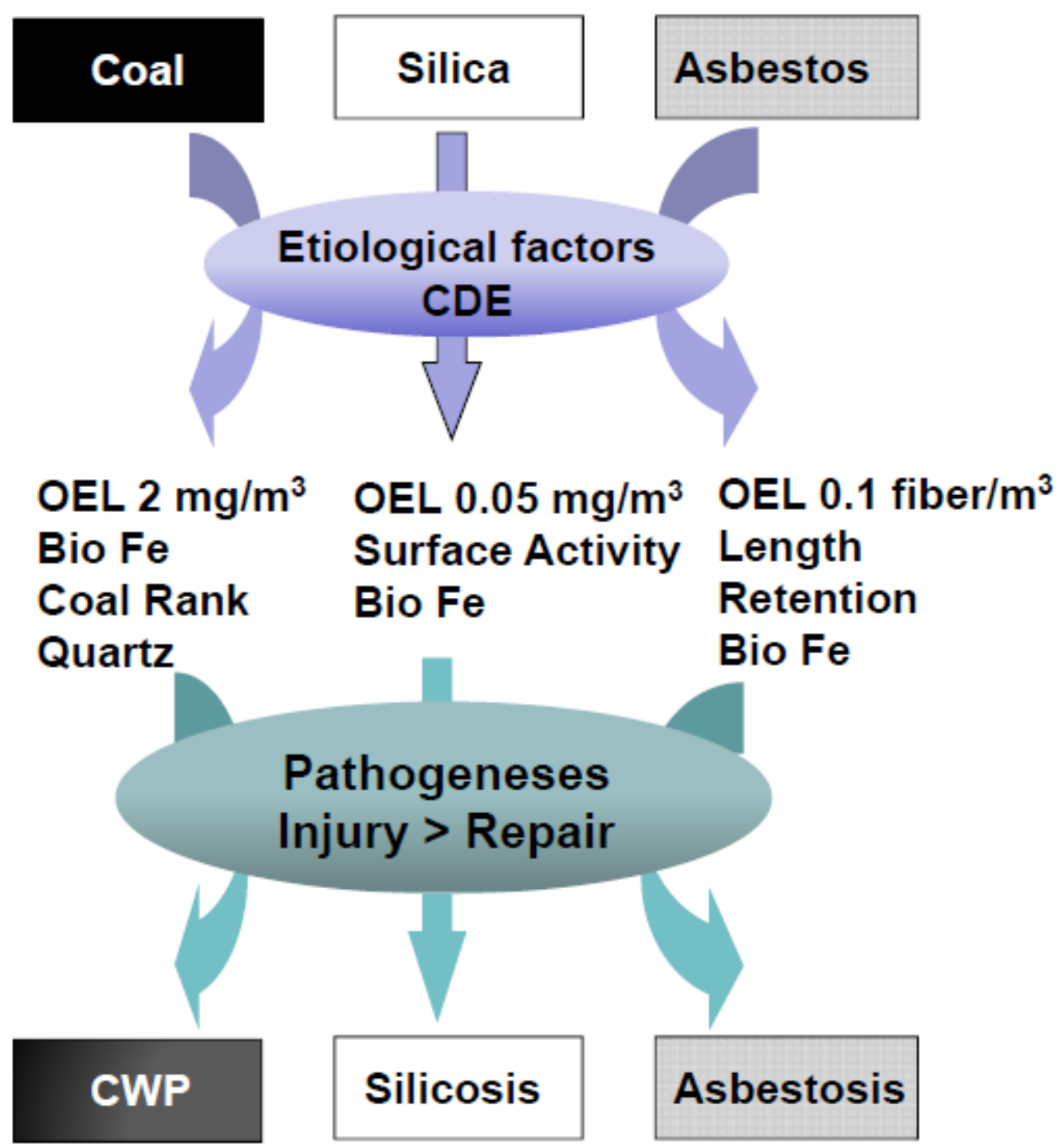

Figure 1. Summary of the etiological factors of CWP, silicosis, and asbestosis. Cumulative dust exposure (CDE) is the most important etiological factor in the occupational diseases. Another common factor is the level of bioavailable iron (Bio Fe) in coals, silica, and asbestos.

Generation of oxidants by the inhaled particles as well as by the activated cells such as alveolar macrophages (AMs) could result in activation of cell signaling pathways. Activator protein-1 (AP-1), nuclear factor-kappa B (NF- $\mathrm{KB})$, and nuclear factors of activated $\mathrm{T}$ cells (NFAT) are critically important factors to cope with oxidative stress insults in cells. As intensity of oxidative stress increases, kinases such as protein kinase C become activated (34). Upon phosphorylation and nuclear translocation, AP-1 and NF-kB regulate cell migration, proliferation and apoptosis. It has been shown that the coal from the Pennsylvania coalmine region with a high prevalence of CWP transactivates AP-1 and NFAT signaling pathways (35). In contrast, coal from the Utah coalmine region, which has a low prevalence of CWP, has no such effects. The promoter/enhancer regions of many inflammatory cytokine genes contain AP-1, NFAT, and NF- $\mathrm{KB}$ binding sites (36). For example, human interleukin-6 (IL-6) gene promoter and enhancer region contains several binding sites of NF- $\kappa \mathrm{B}$, AP-1, and CREB (cAMP-responsive element 
binding protein) (37). In experiments to assess AP-1 as a candidate for coal-mediated IL-6 transcriptional activation, specific inhibitors of AP-1 pathways such as PD98509 and SB203580, two specific inhibitors of MEK1 (ERKs pathway) and p38 MAPK, were shown to abolish coalinduced IL-6 mRNA and protein expressions (38). Several reports have also demonstrated AP-1 and $\mathrm{NF}-\kappa \mathrm{B}$ activation by quartz (39) and asbestos (40).

The Nalp3 inflammasome in AMs has been identified as a major proinflammatory sensor for silica and asbestos, which stimulates the secretion of mature IL-1 $\beta$ (41, 42). Mature IL-1 $\beta$ is produced by cleavage of the inactive pro-IL-1 $\beta$ precursor by caspase- 1 , which is activated within a large multiprotein complex, termed the inflammasome (43). The inflammatory response and subsequent development of lung fibrosis after inhalation of silica is dependent on Nalp3 inflammasome (41). In a model of asbestos inhalation, Nalp3 knockout $\left(\mathrm{Nalp3}^{-/-}\right)$mice showed diminished recruitment of inflammatory cells to the lungs, paralleled by lower cytokine production (42). Coal dust has not been tested in the Nalp3 inflammasome studies $(41,42)$.

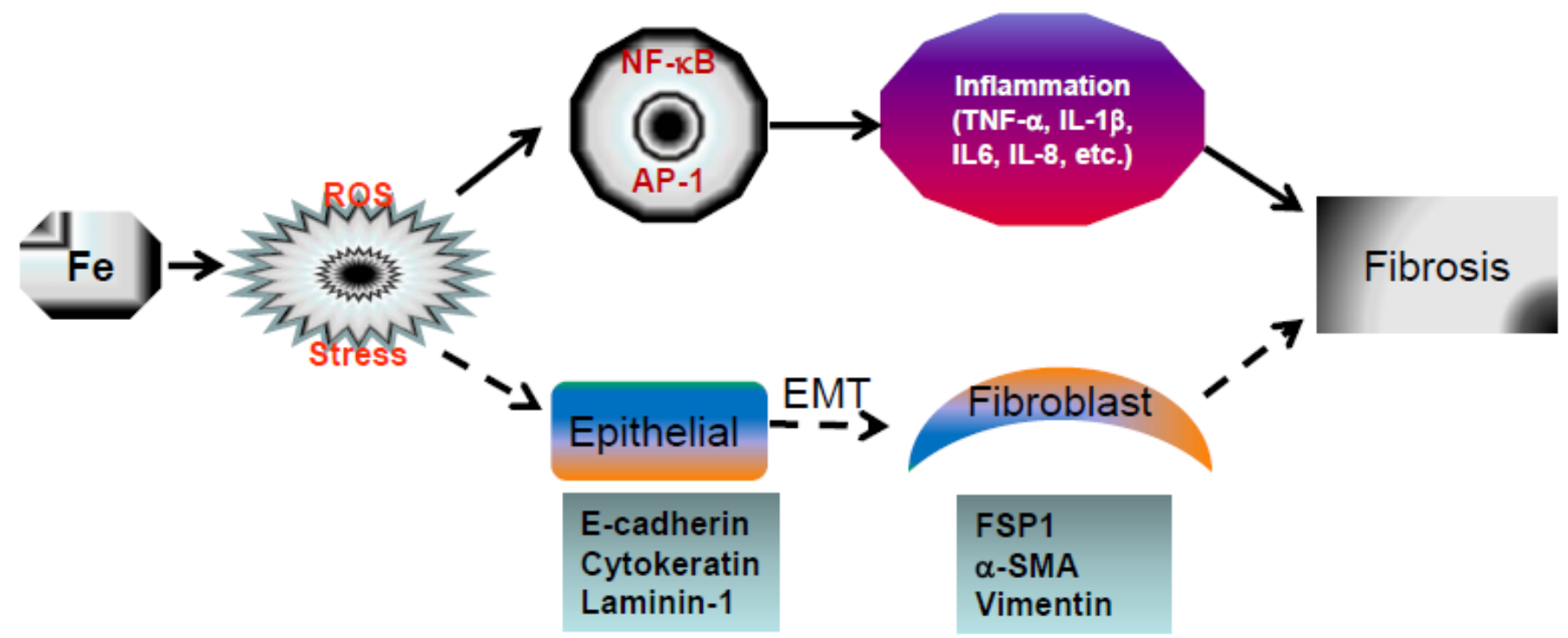

Figure 2. Pathogeneses of CWP, silicosis, and asbestosis. Iron-mediated reactive oxygen species (ROS) cause oxidative stress and increase inflammation by eliciting, for instance via nuclear factor kappa B (NF- $\mathrm{B}$ ) and activator protein 1 (AP-1), the production of cytokines like tumor necrosis factor-alpha (TNF- $\alpha$ ) and interleukins (IL)-1 $\beta, 6$, and 8. Epithelial mesenchymal transition (EMT) may be involved in the process of fibrosis development. FSP-1: fibroblast-specific protein-1; $\alpha$-SMA: alpha-smooth muscle actin.

Particles on the alveolar surface, which are not cleared by AMs, can be transported rapidly across the epithelium to the interstitium (44). Type II cells grow and divide to epithelialize the alveolar surface through differentiation. They express proteases, which play a role in clearing fibrin deposits from the alveolar space. It has become increasingly evident that epithelialmesenchymal transition (EMT) during tissue injury plays an important role in organ fibrosis
(Figure 2) $(45,46)$. Such EMT is found to be associated with progressive fibrosis occurring in kidney, lung, liver, and intestine (47-49). Direct evidence indicates that alveolar epithelial cells serve, via EMT, as important precursors of fibroblasts that arise during the course of organ fibrosis $(50,51)$.

The term EMT describes a series of events during which epithelial cells lose many of their epithelial characteristics such as expression of E- 
cadherin and laminin and take on properties that are typical of mesenchymal cells (46). Fibroblastspecific protein 1 (FSP1), alpha-smooth muscle actin ( $\alpha$-SMA) and collagen-1 are reliable markers of the mesenchymal cells. These markers, along with discoidin receptor tyrosine kinase 2, vimentin, and desmin, have been used to identify epithelial cells that are in the midst of undergoing an EMT associated with chronic inflammation. Such cells, probably representing the intermediate stages of EMT, continue to exhibit epithelialspecific morphology but showed concomitant expression of the mesenchymal markers FSP1 and $\alpha$-SMA. Ultimately, these cells shed all of their epithelial markers and gain a fully fibroblast phenotype. They disrupt the epithelial layers via degradation of the basement membrane, accumulate in the interstitium of the tissue, and contribute to fibrosis development. Whether coal, silica, and asbestos induce EMT is still an unknown matter, which needs to be further investigated (30).

\subsection{Other risk predictors of CWP}

While CDE is the most important risk factor, striking regional differences in the prevalence of CWP exist among different coal mine regions despite comparable dust exposure. For example, in the U.S., the disease is more common in Pennsylvania than in the rest of Appalachia. It occurs less frequently in the Mid-West and much less so in the West (52). In France, coal miners of Provence did not display CWP $(0 \%)$ whereas the prevalence of CWP in coal miners of Nord Pas de Calais was $24 \%$ (53). In Great Britain, the proportional mortality ratios for CWP varied from 135 (95\% CI 16-488) in Leicestershire county to 3825 (95\% CI 1538-7881) in South Glamorgan county (54). The observed regional differences in the prevalence of CWP indicate that the physicochemical characteristics of coal mine dust responsible for CWP development may vary from region to region.

Coal rank, quartz content, and levels of bioavailable iron in the coal, have been shown to play important roles in the regional differences, which were reviewed in detail $(29,55)$. It is noteworthy that buffering capacity of the coals appears to be the most important chemical component controlling the dissolution of coal particles and, thus, release of bioavailable iron and cleaning of quartz surface for biological activities. Buffering capacities of coals are directly related to the presence of calcite $\left(\mathrm{CaCO}_{3}\right)$ in the coals (56). The coals from Western U.S., such as Utah and Colorado contain higher levels of calcite than those from Pennsylvania and West Virginia coal mines. Epidemiological studies showed that coals from Utah and Colorado are less hazardous to coal workers than the coals from Pennsylvania and West Virginia.

In addition to the physico-chemical nature of the coal, genetic factors may also contribute to the regional differences in the prevalence of CWP. Some individuals may be susceptible to coal dust exposure but others may not. It is widely known and accepted that there is large variation between individuals in their response to air pollutants (57). Genetic association studies have compared the adverse effects of air pollutants between subjects with specific genotypes in biologically relevant genes. In human studies of ozone exposure, polymorphisms in oxidative stress genes, such as nicotinamide adenine dinucleotide dehydrogenase, quinone 1 (NQO1), glutathione S-transferase M1 (GSTM1), glutathione S-transferase pi (GSTP1), modify respiratory symptoms, lung function, and serve as biomarkers and risk predictors of asthma (57-61). Inflammatory gene polymorphisms (e.g., tumor necrosis factor or TNF) influence the lung function response to ozone and the effect of different levels of ozone on the development of asthma. Polymorphisms in oxidative stress genes (GSTM1, GSTP1) alter the response to combined exposure of ragweed pollen and diesel exhaust particles (61). In a small sample size study, GSTT1 gene deletion has been suggested to have a protective effect on the development of asbestosis $(62,63)$. Polymorphisms in the tumor necrosis factor-alpha (TNF- $\alpha)$ gene promoter may predispose workers to severe silicosis (64). Although there is no positive study linking genetic susceptibility to CWP (65), it is conceivable that genetic factors play a role in the disease.

\subsection{Proposed prevention of CWP}

According to the knowledge gained through reduction of silicosis and asbestosis, four strata of

(C) 2011 by NWPII. All rights reserved. 
protection can be used to end the recent uptrend in CWP prevalence (Figure 3). The first practical measure is to reduce coal dust levels at the work setting by strictly enforcing the OEL and the time a worker spends in the dusty area. Improved ventilation, the use of water spray to wet and capture airborne dust, inclusion of additives such as foams into the water spray, and optimizing the cutting tools to generate less dust are current dust control strategies in underground coalmines (66). An administrative control could be added to remove the worker from the dusty environment rather than removing dust from the environment. Developing better means of controlling dust levels in and around mines and managing work hours to reduce $\mathrm{CDE}$ would be effective in preventing CWP.

When exposure to coal dust is unavoidable because dust reduction may have been maximized, the second step is to use better understandings of coal properties to predict and/or decrease the toxicity of the coal dust. It has been proposed that levels of bioavailable iron in the coals can be used to predict coals' toxicity, even before large-scale mining (24). Coal from the West Coast has been found to contain large amounts of calcite, which prevents iron in the coal from becoming bioavailable (56). Calcite can easily react with acid to produce $\mathrm{Ca}^{2+}$ ions and $\mathrm{CO}_{2}$, which are nontoxic. The consumption of the acid will accelerate the oxidation of bioavailable iron to nonbioavailable form of iron (e.g., goethite, $\mathrm{FeOOH}$ ). Moreover, because $\mathrm{CaCO}_{3}$ is more alkaline than $\mathrm{FeCO}_{3}$ or $\mathrm{FeSiO}_{3}$, the ability of $\mathrm{CaCO}_{3}$ to react with acid in the aqueous medium is stronger than those of $\mathrm{FeCO}_{3}$ or $\mathrm{FeSiO}_{3}$. Under circumstances when only a small amount of acid is available (e.g., phagolysosomes) or calcite is in large excess, no iron can be released to induce oxidative stress and subsequent biological reactions. Silica has also been considered an important toxicant in the coal $(29,67)$ and surface activity of quartz plays a critical role in catalyzing the formation of oxidants $(31,68)$. In the presence of calcite, there are no acids available to clean the surface of quartz, rendering its surface inactive.

\section{CWP Prevention}

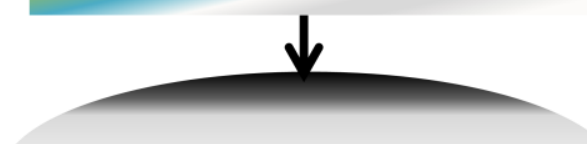

1: Dust reduction

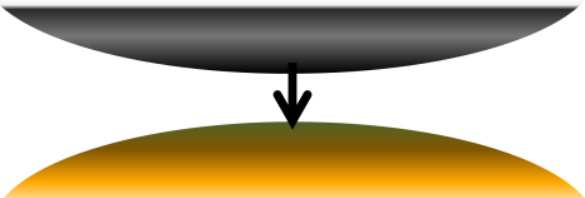

2: Toxicity decrease

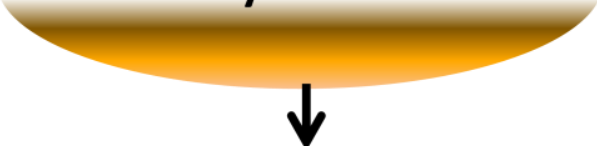

3: Early detection (e.g., Exposure biomarkers)

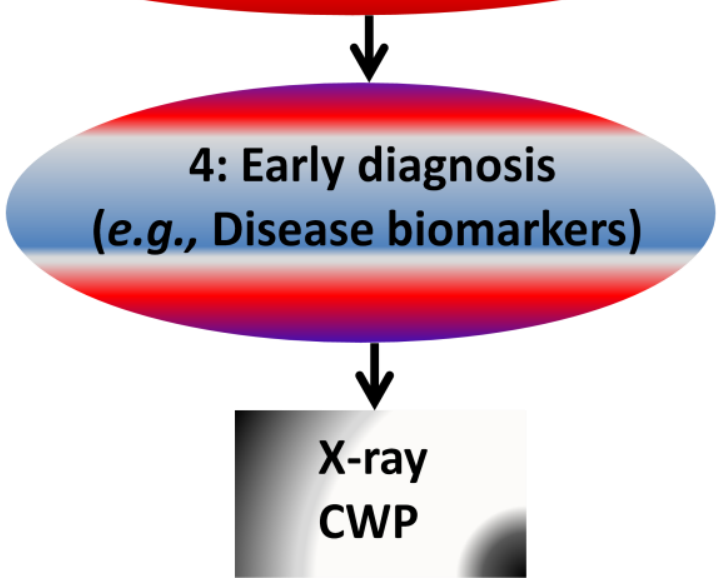

Figure 3. Proposed strategies of CWP prevention before diagnosis by chest $\boldsymbol{x}$ ray. Step 1 is to reduce dust concentration in the work setting; step 2 is to predict and decrease the toxicity of coal during mining; step 3 is to develop exposure biomarkers such as changes in iron levels to quantify exposure of individual coal workers; step 4 is to explore disease biomarkers to identify those who are likely susceptible to CWP development. These steps are early prevention and detection measures that should be taken before diagnosis of CWP by chest $x$ ray.

Calcite is widely used in the coal industry; it is the main constituent of rock dust, applied in underground mines for prevention of explosions, and has long been recognized in the treatment of 
acid mine drainage. Pulverized calcite is added to the boilers of coal-fired power plants to absorb $\mathrm{SO}_{2}$ and $\mathrm{NO}_{\mathrm{x}}$, important components of acid rain. By adding calcite into the Pennsylvania coals, it was shown that calcite decreased bioavailable iron levels, but increased $\mathrm{Ca}^{2+}$ levels as well as $\mathrm{pH}$ in the aqueous coal suspensions (69). These results indicate that calcite in the coals may prevent lung disease and may be applied as a dust mitigation strategy to reduce coal's toxicity. This dust mitigation could be implemented through engineering modification to existing technology.

Third, biomarkers of exposure should be developed to predict and quantify exposure and dose. Based on the hypothesis that iron induces ROS and inflammation and causes lung injury and CWP, inhalation of iron-containing dust should alter body iron status. Increased total systemic iron stores, as evidenced by increased serum ferritin levels, were reported in welders who are exposed to iron dusts $(70,71)$. Therefore, changes in levels of serum iron, transferrin saturation rate, soluble transferrin receptor (sTfR), and ferritin should be evaluated as exposure biomarkers for toxic coal. Because of the opposite regulation of transferrin receptor and ferritin by iron, the ratio of sTfR/ferritin could be used as a sensitive biomarker of exposure to iron-containing coal (72).

Last, early biomarkers of the disease should be developed. When coal dust-induced cellular injury exceeds cellular repair capacity, CWP starts to develop. When coal workers take $x$-rays and there are opacities in the lung, CWP has occurred and it is often too late to stop the disease progression. Therefore, early disease biomarkers with quantifiable changes in serum rather than in BAL should be identified and validated for early detection. TNF- $\alpha$, IL-6, IL- 8 and transforming growth factor-beta (TGF- $\beta$ ) are critical in inflammation, fibrosis, and other diseases (73-75). AMs from pneumoconiotic patients were shown to spontaneously produce large amounts of oxidants, TNF- $\alpha$, IL-6, TGF- $\beta$, and fibronectin $(76,77)$. Although these cytokines and factors in the serum are properties shared by many inflammatory states and not necessarily linked to CWP, higher exposure and disease biomarkers in serum may be initially investigated with $x$-ray. Validation of these markers may offer an opportunity of early detection. Those coal workers identified at high risk of developing CWP should be transferred to avoid further coal dust exposure and CWP progression. In conclusion, through these multiple strata of the protection, CWP is preventable.

\section{Acknowledgements}

This work was supported by a grant from the National Institute for Occupational Safety and Health (1 R01 OH009771).

Competing financial interest declaration: None

\section{References}

1. 1. NIOSH: Work-related lung disease surveillance report 2007. In: Division of Respiratory Studies., 2008: Department of Health and Human Services. Pages 41-43.

2. Gross P. Pneumoconiosis. The dilemma of definition and classification. Arch Environ Health. 1962, 5:269-270.

3. Honma K., Abraham J. L., Chiyotani K., De Vuyst P., Dumortier P., Gibbs A. R., Green F. H., Hosoda Y., Iwai K., Williams W. J., Kohyama N., Ostiguy G., Roggli V. L., Shida H., Taguchi O., Vallyathan V. Proposed criteria for mixed-dust pneumoconiosis: definition, descriptions, and guidelines for pathologic diagnosis and clinical correlation. Human Pathol. 2004, 35:1515-1523.

4. Castranova V., Vallyathan V. Silicosis and coal workers' pneumoconiosis. Environ Health Perspect. 2000, 108 Suppl 4:675-684.

5. Levine D. G., Schlosberg R. H., Silbernagel B. G. Understanding the chemistry and physics of coal structure: A Review. Proc Natl Acad Sci U S A. 1982, 79:3365-3370.

6. Meyers R. A.: Coal Structure, 1982. New York: Academic Press.

7. Finkelman R. B.: Modes of occurrence of environmentally-sensitive trace elements in coal. In: Environmental Aspects of Trace Elements. Edited by Swaine DJ, Goodarzi F. Boston: Kluwer Academic Publishers;pp. 24$50 ; 1995$.

(C) 2011 by NWPII. All rights reserved.

102 
8. Madl A. K., Donovan E. P., Gaffney S. H., McKinley M. A., Moody E. C., Henshaw J. L., Paustenbach D. J. State-of-the-science review of the occupational health hazards of crystalline silica in abrasive blasting operations and related requirements for respiratory protection. $J$ Toxicol Environ Health B Crit Rev. 2008, 11:548-608.

9. Anonymous. Silicosis mortality, prevention, and control--United States, 1968-2002. MMWR Morb Mortal Wkly Rep. 2005, 54:401405.

10. Liu G., Beri R., Mueller A., Kamp D. W. Molecular mechanisms of asbestos-induced lung epithelial cell apoptosis. Chem Biol Interact. 2010, 188:309-318. DOI: 10.1016/j.cbi.2010.03.047:

11. Hnizdo E., Murray J., Sluis-Cremer G. K., Thomas R. G. Correlation between radiological and pathological diagnosis of silicosis: an autopsy population based study. Am J Ind Med. 1993, 24:427-445.

12. Seixas N. S., Robins T. G., Attfield M. D., Moulton L. H. Exposure-response relationships for coal mine dust and obstructive lung disease following enactment of the Federal Coal Mine Health and Safety Act of 1969. Am J Ind Med. 1992, 21:715-734.

13. Seixas N. S., Checkoway H. Exposure assessment in industry specific retrospective occupational epidemiology studies. Occup Environ Med. 1995, 52:625-633.

14. Attfield M. D., Morring K. The derivation of estimated dust exposures for U.S. coal miners working before 1970. Am Ind Hyg Assoc J. 1992, 53:248-255.

15. Naidoo R. N., Robins T. G., Solomon A., White N., Franzblau A. Radiographic outcomes among South African coal miners. Int Arch Occup Environ Health. 2004, 77:471481.

16. Attfield M. D., Morring K. An investigation into the relationship between coal workers' pneumoconiosis and dust exposure in U.S. coal miners. Am Ind Hyg Assoc J. 1992, 53:486-492.

17. Attfield M. D., Hodous T. K. Pulmonary function of U.S. coal miners related to dust exposure estimates. Am Rev Respir Dis. 1992, 145:605-609.

18. Soutar C. A., Hurley J. F., Miller B. G., Cowie H. A., Buchanan D. Dust concentrations and respiratory risks in coalminers: key risk estimates from the British Pneumoconiosis Field Research. Occup Environ Med. 2004, 61:477-481.

19. Brown T. P., Rushton L. Mortality in the UK industrial silica sand industry: 1. Assessment of exposure to respirable crystalline silica. Occup Environ Med. 2005, 62:442-445.

20. Hedlund U., Jonsson H., Eriksson K., Jarvholm B. Exposure-response of silicosis mortality in Swedish iron ore miners. Ann Occup Hyg. 2008, 52:3-7.

21. Steenland K. One agent, many diseases: exposure-response data and comparative risks of different outcomes following silica exposure. Am J Ind Med. 2005, 48:16-23.

22. Laney A. S., Petsonk E. L., Attfield M. D. Pneumoconiosis among underground bituminous coal miners in the United States: is silicosis becoming more frequent? Occup Environ Med. 2010, 67:652-656. DOI: 10.1136/oem.2009.047126:

23. Laney A. S., Attfield M. D. Coal workers' pneumoconiosis and progressive massive fibrosis are increasingly more prevalent among workers in small underground coal mines in the United States. Occup Environ Med. 2010, 67:428-431.

24. Huang X., Li W., Attfield M. D., Nadas A., Frenkel K., Finkelman R. B. Mapping and prediction of coal workers' pneumoconiosis with bioavailable iron content in the bituminous coals. Environ Health Perspect. 2005, 113:964-968.

25. Laney A. S., Petsonk E. L., Attfield M. D. Pneumoconiosis among underground bituminous coal miners in the United States: is silicosis becoming more frequent? Occup Environ Med. 2010:67:652-656.

26. Crosby L. M., Waters C. M. Epithelial repair mechanisms in the lung. Am J Physiol Lung Cell Mol Physiol. 2010, 298:L715-731. DOI: 10.1152/ajplung.00361.2009:

27. Shi X., Castranova V., Halliwell B., Vallyathan V. Reactive oxygen species and 
silica-induced carcinogenesis. $J$ Toxicol Environ Health B Crit Rev. 1998, 1:181-197.

28. Huang $X$. Iron overload and its association with cancer risk in humans: evidence for iron as a carcinogenic metal. Mutat Res. 2003, 533:153-171.

29. Huang X., Finkelman R. B. Understanding the chemical properties of macerals and minerals in coal and its potential application for occupational lung disease prevention. $J$ Toxicol Environ Health B Crit Rev. 2008, 11:45-67.

30. Kamp D. W. Asbestos-induced lung diseases: an update. Transl Res. 2009, 153:143-152. DOI: 10.1016/j.trs1.2009.01.004:

31. Fubini B., Hubbard A. Reactive oxygen species (ROS) and reactive nitrogen species (RNS) generation by silica in inflammation and fibrosis. Free Radic Biol Med. 2003, 34:1507-1516.

32. Ghio A. J., Stonehuerner J., Richards J., Devlin R. B. Iron homeostasis in the lung following asbestos exposure. Antioxid Redox Signal. 2008, 10:371-377. DOI: 10.1089/ars.2007.1909:

33. Zhang Q., Huang X. Induction of ferritin and lipid peroxidation by coal samples with different prevalence of coal workers' pneumoconiosis: role of iron in the coals. Am J Ind Med. 2002, 42:171-179. DOI: 10.1002/ajim.10101:

34. Lushchak V. I. Adaptive response to oxidative stress: Bacteria, fungi, plants and animals. Comp Biochem Physiol C Toxicol Pharmacol. 2011, 153:175-190. DOI: 10.1016/j.cbpc.2010.10.004:

35. Huang C., Li J., Zhang Q., Huang X. Role of bioavailable iron in coal dust-induced activation of activator protein-1 and nuclear factor of activated T cells: Difference between Pennsylvania and Utah coal dusts. Am J Respir Cell Mol Biol. 2002, 27:568-574.

36. Macian F., Lopez-Rodriguez C., Rao A. Partners in transcription: NFAT and AP-1. Oncogene. 2001, 20:2476-2489.

37. Hirano T.: Interleukin-6. In: The Cytokine Handbook, 3rd edition. Edited by Thomson A. New York: Academic Press;pp. 197-228; 1998.
38. Huang X., Zhang Q. Coal-induced interleukin-6 gene expression is mediated through ERKs and p38 MAPK pathways. Toxicol Appl Pharmacol. 2003, 191:40-47.

39. van Berlo D., Knaapen A. M., van Schooten F. J., Schins R. P., Albrecht C. NF-kappaB dependent and independent mechanisms of quartz-induced proinflammatory activation of lung epithelial cells. Part Fibre Toxicol. 2010, 7:13. DOI: 10.1186/1743-8977-7-13:

40. Altomare D. A., Menges C. W., Pei J., Zhang L., Skele-Stump K. L., Carbone M., Kane A. B., Testa J. R. Activated TNF-alpha/NFkappaB signaling via down-regulation of Fasassociated factor 1 in asbestos-induced mesotheliomas from Arf knockout mice. Proc Natl Acad Sci U S A. 2009, 106:3420-3425. DOI: $10.1073 /$ pnas.0808816106:

41. Cassel S. L., Eisenbarth S. C., Iyer S. S., Sadler J. J., Colegio O. R., Tephly L. A., Carter A. B., Rothman P. B., Flavell R. A., Sutterwala F. S. The Nalp3 inflammasome is essential for the development of silicosis. Proc Natl Acad Sci U S A. 2008, 105:9035-9040. DOI: 10.1073/pnas.0803933105:

42. Dostert C., Petrilli V., Van Bruggen R., Steele C., Mossman B. T., Tschopp J. Innate immune activation through Nalp3 inflammasome sensing of asbestos and silica. Science. 2008, 320:674-677. DOI: 10.1126/science.1156995:

43. Martinon F., Burns K., Tschopp J. The inflammasome: a molecular platform triggering activation of inflammatory caspases and processing of proIL-beta. Mol Cell. 2002, 10:417-426. DOI: S1097276502005993 [pii]:

44. Heppleston A. G. Relationship of lipid secretion and particle size to diffuse interstitial change in pneumoconiosis: a pathogenetic perspective. Am J Ind Med. 1989, 15:427-439.

45. Kalluri R., Neilson E. G. Epithelialmesenchymal transition and its implications for fibrosis. J Clin Invest. 2003, 112:17761784.

46. Kalluri R., Weinberg R. A. The basics of epithelial-mesenchymal transition. J Clin Invest. 2009, 119:1420-1428.

47. Kim K. K., Kugler M. C., Wolters P. J., Robillard L., Galvez M. G., Brumwell A. N., Sheppard D., Chapman H. A. Alveolar 
epithelial cell mesenchymal transition develops in vivo during pulmonary fibrosis and is regulated by the extracellular matrix. Proc Natl Acad Sci U S A. 2006, 103:1318013185.

48. Zeisberg E. M., Tarnavski O., Zeisberg M., Dorfman A. L., McMullen J. R., Gustafsson E., Chandraker A., Yuan X., Pu W. T., Roberts A. B., Neilson E. G., Sayegh M. H., Izumo S., Kalluri R. Endothelial-to-mesenchymal transition contributes to cardiac fibrosis. Nat Med. 2007, 13:952-961.

49. Zeisberg M., Yang C., Martino M., Duncan M. B., Rieder F., Tanjore H., Kalluri R. Fibroblasts derive from hepatocytes in liver fibrosis via epithelial to mesenchymal transition. J Biol Chem. 2007, 282:2333723347.

50. Okada H., Danoff T. M., Kalluri R., Neilson E. G. Early role of Fsp1 in epithelialmesenchymal transformation. Am J Physiol. 1997, 273:F563-574.

51. Strutz F., Okada H., Lo C. W., Danoff T., Carone R. L., Tomaszewski J. E., Neilson E. G. Identification and characterization of a fibroblast marker: FSP1. J Cell Biol. 1995, 130:393-405.

52. Morgan W. K. C., Burgess D. B., Jacobson G., O'Brien R. J., Pendergrass E., Reger R. B., Shoub E. P. The prevalence of coal workers' pneumoconiosis in US coal miners. Arch Environ Health. 1973, 27:221-230.

53. Amoudru C. Les pneumoconioses - dimension actuelle des problemes. Colloque INSERM. 1987, 155:3-40.

54. Coggon D., Inskip H., Winter P., Pannett B. Contrasting geographical distribution of mortality from pneumoconiosis and chronic bronchitis and emphysema in British coal miners. Occup Environ Med. 1995, 52:554555.

55. McCunney R. J., Morfeld P., Payne S. What component of coal causes coal workers' pneumoconiosis? J Occup Environ Med. 2009, 51:462-471.

56. Huang X., Fournier J., Koenig K., Chen L. C. Buffering capacity of coal and its acid-soluble Fe2+ content: possible role in coal workers' pneumoconiosis. Chem Res Toxicol. 1998, 11:722-729.

57. Yang I. A., Fong K. M., Zimmerman P. V., Holgate S. T., Holloway J. W. Genetic susceptibility to the respiratory effects of air pollution. Thorax. 2008, 63:555-563.

58. Alexeeff S. E., Litonjua A. A., Wright R. O., Baccarelli A., Suh H., Sparrow D., Vokonas P. S., Schwartz J. Ozone exposure, antioxidant genes, and lung function in an elderly cohort: VA normative aging study. Occup Environ Med. 2008, 65:736-742.

59. Islam T., McConnell R., Gauderman W. J., Avol E., Peters J. M., Gilliland F. D. Ozone, oxidant defense genes, and risk of asthma during adolescence. Am J Respir Crit Care Med. 2008, 177:388-395.

60. Romieu I., Ramirez-Aguilar M., Sienra-Monge J. J., Moreno-Macias H., del Rio-Navarro B. E., David G., Marzec J., Hernandez-Avila M., London S. GSTM1 and GSTP1 and respiratory health in asthmatic children exposed to ozone. Eur Respir J. 2006, 28:953-959.

61. Yang I. A., Fong K. M., Zimmerman P. V., Holgate S. T., Holloway J. W. Genetic susceptibility to the respiratory effects of air pollution. Postgrad Med J. 2009, 85:428-436.

62. Neri M., Ugolini D., Dianzani I., Gemignani F., Landi S., Cesario A., Magnani C., Mutti L., Puntoni R., Bonassi S. Genetic susceptibility to malignant pleural mesothelioma and other asbestos-associated diseases. Mutat Res. 2008, 659:126-136.

10.1016/j.mrrev.2008.02.002:

63. Franko A., Dodic-Fikfak M., Arneric N., Dolzan V. Glutathione S-transferases GSTM1 and GSTT1 polymorphisms and asbestosis. $J$ Occup Environ Med. 2007, 49:667-671. DOI: 00043764-200706000-00010 [pii]:

64. Corbett E. L., Mozzato-Chamay N., Butterworth A. E., De Cock K. M., Williams B. G., Churchyard G. J., Conway D. J. Polymorphisms in the tumor necrosis factoralpha gene promoter may predispose to severe silicosis in black South African miners. Am J Respir Crit Care Med. 2002, 165:690-693.

65. Zhai R., Liu G., Ge X., Yang C., Huang C., Wu C., Christiani D. C. Genetic polymorphisms of MnSOD, GSTM1, GSTT1, 
and OGG1 in coal workers' pneumoconiosis. $J$ Occup Environ Med. 2002, 44:372-377.

66. Kissell F. N.: Dust control methods in tunnels and underground mines. In: Handbook for Dust Control in Mining. 2003. Pittsburg: NIOSH; 3-22.

67. Cohen R. A., Patel A., Green F. H. Lung disease caused by exposure to coal mine and silica dust. Semin Respir Crit Care Med. 2008, 29:651-661.

68. Ghio A. J., Kennedy T. P., Schapira R. M., Crumbliss A. L., Hoidal J. R. Hypothesis: is lung disease after silicate inhalation caused by oxidant generation? Lancet. 1990, 336:967969.

69. Zhang Q., Huang X. Addition of calcite reduces iron's bioavailability in the Pennsylvania coals--potential use of calcite for the prevention of coal workers' lung diseases. $J$ Toxicol Environ Health A. 2005, 68:16631679.

70. Fidan F., Esme H., Unlu M., Acar M., Albayrak R., Dilek F. H. Welder's lung associated with pneumothorax. $J$ Thorac Imaging. 2005, 20:120-122. DOI: 00005382200505000-00013 [pii]:

71. Doherty M. J., Healy M., Richardson S. G., Fisher N. C. Total body iron overload in welder's siderosis. Occup Environ Med. 2004, 61:82-85.

72. Zeleniuch-Jacquotte A., Zhang Q., Dai J., Shore R. E., Arslan A. A., Koenig K. L., Karkoszka J., Afanasyeva Y., Frenkel K., Toniolo P., Huang X. Reliability of serum assays of iron status in postmenopausal women. Ann Epidemiol. 2007, 17:354-358. DOI: 10.1016/j.annepidem.2006.07.004:

73. Borm P. J., Schins R. P. Genotype and phenotype in susceptibility to coal workers' pneumoconiosis. the use of cytokines in perspective. Eur Respir J Suppl. 2001, 32:127s-133s.

74. Gao X., Picchi A., Zhang C. Upregulation of TNF-alpha and Receptors Contribute to Endothelial Dysfunction in Zucker Diabetic Rats. Am J Biomed Sci. 2010, 2:1-12. DOI: 10.5099/aj100100001:

75. Zhang H., Zhang C. Regulation of Microvascular Function by Adipose Tissue in Obesity and Type 2 Diabetes: Evidence of an Adipose-Vascular Loop. Am J Biomed Sci. 2009, 1:133-142.

76. Borm P. J., Palmen N., Engelen J. J., Buurman W. A. Spontaneous and stimulated release of tumor necrosis factor-alpha (TNF) from blood monocytes of miners with coal workers' pneumoconiosis. Am Rev Respir Dis. 1988, 138:1589-1594.

77. Lassalle P., Gosset P., Aerts C., Fournier E., Lafitte J. J., Degreef J. M., Wallaert B., Tonnel A. B., Voisin C. Abnormal secretion of interleukin-1 and tumor necrosis factor alpha by alveolar macrophages in coal worker's pneumoconiosis: comparison between simple pneumoconiosis and progressive massive fibrosis. Exp Lung Res. 1990, 16:73-80. 